\title{
Vitaliti Semasa Bahasa Melayu di Negara Brunei Darussalam
}

\section{Current Vitality of Malay Language in Brunei Darussalam}

\author{
NAJIB NOORASHID \\ Fakulti Sastera dan Sains Sosial, Universiti Brunei Darussalam, Brunei Darussalam \\ noorashid.najib@gmail.com
}

Published online: 29 October 2021

To cite this article: Najib Noorashid. 2021. Vitaliti semasa bahasa Melayu di Negara Brunei Darussalam. KEMANUSIAAN the Asian Journal of Humanities 28(2): 159-187. https://doi.org/10 $.21315 / \mathrm{kajh} 2021.28 .2 .7$

To link to this article: $\mathrm{https}: / /$ doi.org/10.21315/kajh2021.28.2.7

\begin{abstract}
The interminable "Malay vs. English" debate is ubiquitous in the Malay world. Although Malay is the national language, a cultural and identity marker for the Malays, the globalisation and increasing importance of English has prompted concerns on the decline of the Malay language among scholars and the general public. By applying a modified triangulation model with Language and Attitudes Model, Expanded Graded Intergenerational Disruption Scale, and Language Vitality and Endangerment Frameworks, this article discusses language attitudes and vitality of two important variants of Malay in Brunei: Standard Malay and Brunei Malay, amid the bilingual environment in the country, based on data gathered involving Brunei Malay speakers and claims by Malay scholars. The results show that the language attitudes among Bruneian youth towards both languages are positive and both variants are preserved through local maintenance efforts. Both variants also exist complementary to English depending on contexts and audiences. This article also criticises previous claims on the "threatened" status of Malay language as it also disapproves the accusation that English will become a threat the status and preservation of Malay.
\end{abstract}

Keywords and phrases: language attitude, language vitality, Malay, English, Brunei Darussalam

\begin{abstract}
Abstrak. Perdebatan mengenai "pertelingkahan bahasa Melayu dan bahasa Inggeris" sentiasa wujud di alam Melayu. Walaupun bahasa Melayu merupakan bahasa rasmi/ bahasa kebangsaan dan juga bahasa penanda budaya dan identiti orang Melayu, masih terdapat kekhuatiran terhadap kemungkinan kepupusan bahasa tersebut dalam kalangan para sarjana dan masyarakat Melayu. Perkara ini terjadi kerana peningkatan kepentingan bahasa Inggeris dalam era globalisasi. Dengan mengaplikasikan Model Sikap Bahasa dan metode Skala Penilaian Gangguan Antara Generasi Luasan serta Rangka Kerja
\end{abstract}


Keberdayaan dan Kepupusan Bahasa, makalah ini membincangkan sikap bahasa dan daya hidup semasa bagi dua variasi bahasa Melayu iaitu bahasa Melayu standard dan bahasa Melayu Brunei dalam persekitaran dwibahasa di Negara Brunei Darussalam, berdasarkan bukti-bukti kajian analisis terhadap penutur bahasa Melayu Brunei dan tanggapan beberapa sarjana bahasa Melayu. Hasil analisis mendapati sikap para belia terhadap kedua-dua variasi bahasa adalah positif dan kewujudan dilestarikan melalui usaha-usaha penyelenggaraan setempat, selain kedua-dua variasi bahasa ini saling melengkapi dengan bahasa Inggeris mengikut kesesuaian konteks dan audiens. Makalah ini turut menyangkal tanggapan yang menyatakan kedudukan dan daya hidup semasa bahasa Melayu terancam, selain turut menyanggah dakwaan kewujudan bahasa Inggeris mengancam status dan pengekalan bahasa Melayu.

Kata kunci dan frasa: sikap bahasa, vitaliti bahasa, bahasa Melayu, bahasa Inggeris, Brunei Darussalam

\section{Pengenalan}

Pengekalan dan pencergasan penggunaan bahasa Melayu merupakan salah satu isu linguistik utama di Negara Brunei Darussalam (Brunei). Perkara ini wujud kerana kebimbangan para ahli linguistik dan penutur Melayu mengenai isu identiti, nasionalisme dan elemen-elemen kebudayaan Melayu yang menghadapi cabaran penggunaan bahasa Inggeris yang semakin meluas. Oleh sebab bahasa Melayu merupakan simbol identiti dan penanda perpaduan dalam kalangan penutur Melayu di Brunei, selain diiktiraf sebagai bahasa rasmi, maka isu imperialisme bahasa tentulah isu yang signifikan untuk dicermati.

Makalah ini membincangkan isu keberdayaan bahasa Melayu di Brunei dengan mengaplikasikan gabungan Model Sikap Bahasa yang diubah suai agar lebih komprehensif. Kajian yang berbentuk empirikal ini melibatkan sejumlah penutur dan pakar bahasa Melayu. Kajian ini menggunakan gabungan Model Sikap Bahasa (Baker 1992), Skala Penilaian Gangguan Antara Generasi Luasan atau Expanded Graded Intergenerational Disruption Scale (EGIDS) (Lewis dan Simons 2010) dan Rangka Kerja Keberdayaan dan Kepupusan Bahasa atau Language Vitality and Endangerment (LVE) (United Nations Educational, Scientific and Cultural Organization, UNESCO 2011).

Fokus makalah ini adalah kepada penggunaan dan keberdayaan dua variasi bahasa Melayu yang penting di Brunei, iaitu bahasa Melayu standard dan bahasa Melayu Brunei, di samping penggunaan bahasa Inggeris di negara berbilang bahasa tersebut. Perbezaan kedua-dua variasi bahasa ini boleh dikesan dari aspek fonologi, morfologi dan leksikon (Clynes 2001), namun bahasa Melayu Brunei 
turut berkongsi sebanyak 84\% leksikon utama dengan bahasa Melayu standard (Nothofer 1991).

\section{Hubungan Sikap Bahasa dan Keberdayaan Bahasa}

"Sikap bahasa" merujuk kepada sikap penutur atau masyarakat terhadap bahasa, dialek, aksen dan penutur asli. Hal ini berkait rapat dengan kecenderungan positif atau negatif terhadap sesuatu bahasa, sekali gus menggambarkan prospek bahasa tersebut. Kajian terhadap sikap bahasa yang melibatkan penutur boleh menjadi petunjuk kepada tingkah laku linguistik, perubahan atau peralihan bahasa, representasi identiti dan ideologi sesebuah komuniti terhadap bahasa (Trudgill 2003). Oleh yang demikian, sikap bahasa merupakan salah satu indikator penting sosiolinguistik dalam menentukan keberdayaan bahasa, terutama dalam usaha berterusan untuk melestarikan atau mencergaskan penggunaan bahasa tersebut (Baker 1992; Fasold 1984). Sikap bahasa boleh dikenal pasti, dikesan dan diselidiki sama ada secara tersurat (overt), tersirat (covert), atau kedua-duanya.

Sikap positif terhadap bahasa juga penting untuk kewujudan dan kestabilan jangka panjang penggunaan bahasa, sekali gus mempertahankan keberdayaan bahasa. Beberapa faktor luaran seperti pertahanan, ekonomi, agama atau budaya setempat mahupun faktor dalaman seperti sikap masyarakat terhadap bahasa boleh mempengaruhi keberdayaan bahasa manakala unsur-unsur negatif yang mungkin wujud sebagai faktor dalaman dan luaran seperti gangguan penyebaran bahasa, tradisi linguistik dan elemen-elemen kebudayaan antara generasi boleh menyebabkan kemerosotan keberdayaan bahasa (Baker 1996; UNESCO 2003). Faktor-faktor tersebut umumnya adalah generik, yang bermakna ia boleh wujud di mana-mana negara dengan penambahan faktor mengikut landskap negara tersebut. Kajian Noor Azam (2005), Noor Azam dan Siti Ajeerah (2016) dan Najib (2020) terhadap keberdayaan bahasa di Brunei misalnya, menemui faktorfaktor seperti hierarki bahasa, nilai kuasa dan sikap bahasa turut memainkan peranan penting dalam mempengaruhi daya hidup bahasa suatu persekitaran ekolinguistik berbilang bahasa.

\section{Isu Pemberdayaan Bahasa Melayu di Alam Melayu dan Negara Brunei Darussalam}

Cabaran sosiolinguistik di alam Melayu dan di Brunei akibat daripada iklim globalisasi ternyata amat ketara. Penggunaan bahasa Inggeris yang semakin meluas dalam kalangan penutur Melayu serta gejala alih kod bahasa MelayuInggeris atau yang dikenali sebagai bahasa rojak dalam komunikasi harian boleh 
menimbulkan isu kekeliruan identiti (Abdullah 2009; Fathu 2011; Syah 2007). Keadaan ini boleh menjejaskan pengukuhan keberdayaan bahasa Melayu dan kemahiran berbahasa, selain dianggap mencemari ciri-ciri kemelayuan penutur asli (Hashim et al. 2013; Rabiatul 2012). Brunei juga menghadapi cabaran ekoran peningkatan penggunaan bahasa Inggeris dalam sistem pendidikan, sistem kehakiman dan persekitaran kerja. Cabaran ini dipercayai boleh melemahkan penggunaan bahasa Melayu (Azmi 2009; Fatimah 2010; Mataim 2001). Di samping itu, peminjaman kosa kata asing yang berterusan daripada bahasa Inggeris juga dilihat sebagai masalah bagi sesetengah pihak dan pakar bahasa (Abdullah 1983; Darwis 2000; Nurhayati 2009). Sehingga kini, terdapat banyak laporan berkenaan kemerosotan kemahiran berbahasa Melayu akibat kecenderungan menggunakan bahasa Inggeris dalam komunikasi harian (Aminah 2015; Azhari 2016; Zaim 2010). Keadaan ini menimbulkan kekhuatiran terhadap kemungkinan bahasa Inggeris akan menggantikan bahasa Melayu sebagai bahasa pengantar utama di Brunei.

\section{Teori dan Metodologi Kajian}

Makalah ini merungkaikan tiga isu iaitu: (1) Sikap bahasa dan keberdayaan bahasa Melayu, (2) Faktor-faktor psikologi atau sosiologi yang mempengaruhi sikap terhadap bahasa Melayu dan (3) Faktor-faktor kemorosotan bahasa Melayu berdasarkan bukti-bukti analisis menggunakan kajian secara empirikal dengan mengaplikasi model triangulasi yang diubahsuai daripada Model Sikap Bahasa (Baker 1992), EGIDS (Lewis dan Simons 2010) dan LVE (UNESCO 2011). Fokus makalah ini merangkumi penyerlahan sikap bahasa tersirat (covert attitudes) yang dilakukan melalui pemerhatian penggunaan bahasa dalam situasi formal dan informal yang diuji menggunakan ujian tindak balas subjek (subject reaction tests) terhadap empat rakaman suara dalam empat variasi bahasa. Enam jangkaan sifat iaitu "berpendidikan", "cerdik", "berkebolehan", "berdisiplin", "dominan" dan "berstatus sosial tinggi" yang berhubung kait dengan domain kekuasaan, status dan formaliti dikelompokkan dalam domain rasmi/ profesional. Jangkaan sifat yang lain, termasuk "mudah", "indah", "bergaya", "beryakinan", "ramah", "dipercayai" dan "emosional" mewakili bentuk-bentuk semantik yang lebih intim dikategorikan dalam domain solidariti/afektif. Pengujian ini kemudiannya dilengkapi dengan instrumen penilaian kendiri yang berupa soal selidik bagi mewakili sikap bahasa tersurat (overt attitudes) merangkumi pemilihan bahasa dalam situasi dan domain tertentu dan sikap bahasa responden, selain turut melibatkan penilaian kecekapan bahasa dari keputusan peperiksaan bahasa peringkat nasional bersesuaian dengan objektif kajian ini. 
Seramai 200 orang penutur bahasa Melayu Brunei yang berada dalam kumpulan usia antara 20 tahun sehingga 40 tahun dijadikan responden kajian. Jumlah ini terdiri daripada mereka yang menuntut di institusi pendidikan tinggi dan mereka yang terlibat dengan sektor pekerjaan terpilih. Lazimnya, penutur bahasa dalam kumpulan usia ini adalah lebih stabil, matang dan konsisten dalam menggunakan bahasa mengikut keperluan dan motivasi (Ronnlund et al. 2005). Golongan ini juga mempunyai penilaian daya hidup etnolinguistik yang lebih tekal berbanding mereka yang lebih muda dan lebih berusia (Giles et al. 2000). Para responden kajian ini juga berkebolehan dalam menggunakan bahasa Melayu standard, bahasa Melayu Brunei dan bahasa Inggeris memandangkan mereka pernah melalui Sistem Pendidikan Dwibahasa atau Sistem Pendidikan Negara Abad ke-21 (SPN-21) atau kedua-duanya. Mereka dianggap sebagai kumpulan sampel yang berpendidikan (educated sample population) memandangkan mereka juga menuntut di institusi-institusi pendidikan tinggi atau bekerja ketika pengumpulan data dijalankan (Najib 2020, 139). Para responden kajian ini berperanan penting dalam penyelidikan tentang penggunaan dan keberdayaan bahasa kerana mereka merupakan ejen penyebaran bahasa yang bertanggungjawab melestarikan bahasa Melayu sebagai sebahagian daripada tradisi, warisan dan budaya Melayu Brunei.

Seramai lapan pakar bahasa dari Brunei (2), Malaysia (3), Indonesia (2) dan Singapura (1) terlibat dalam siri temu bual bagi mendapatkan lebih banyak data kualitatif yang mewakili perspektif profesional. Sebagai sebahagian daripada triangulasi kajian, temu bual bersama pakar ini dipilih kerana kaedah ini boleh menghasilkan penemuan penyelidikan terbaharu melalui penilaian kendiri dan tersirat pakar, selain menawarkan perspektif terkini berkenaan isu difokuskan yang tidak diperoleh melalui rujukan sekunder (Doringer 2020; Meuser dan Nagel 2009). Metode tersebut juga memberi peluang kepada kajian ini untuk mencapai kesahihan dapatan dan hujah melalui pengetahuan dalaman praktikal (practical insider knowledge) dengan pakar-pakar terpilih secara berterusan (Bogner, Littig dan Menz 2009, 3). Pakar-pakar bahasa ini dipilih berdasarkan karya-karya penulisan dan perspektif mereka terhadap isu-isu kedwibahasaan di alam Melayu sebelum ini. Dua pakar linguistik antarabangsa yang banyak menjalankan kajian kedwibahasaan di alam Melayu dan Asia Tenggara turut ditemu bual bagi mendapatkan perspektif antarabangsa berkenaan isu yang sama. Selain itu, lima pegawai pendidikan tempatan dari Kementerian Pendidikan juga ditemu bual untuk menjelaskan beberapa kekeliruan yang timbul sepanjang kajian dijalankan. Kebenaran untuk menggunakan data temu bual telah diperoleh dan dipersetujui oleh para responden. 
Kajian ini bertujuan menjadi perintis terhadap kajian berkaitan "bahasa Melayu vs. bahasa Inggeris" dengan mengaplikasi pendekatan multi-modal yang komprehensif dan menggunakan perspektif sosiolinguistik yang melibatkan penggunaan bahasa dalam masyarakat secara empirikal. Hal ini termasuk menganalisis sikap bahasa dalaman dan luaran selain menggabungkan kajian dengan dapatan analisis kecekapan bahasa dan wacana profesional, dan seterusnya mentafsirkan dapatan kajian dalam kerangka kerja keberdayaan bahasa. Kajian ini juga mewakili skop penyelidikan yang luas dan menyeluruh dalam memastikan kebolehpercayaan dan kesahihan interpretasi dapatan. Kajian ini memberi tumpuan khusus kepada situasi semasa, penggunaan dan keberdayaan bahasa Melayu di samping bahasa Inggeris di Brunei.

\section{Teori dan Aplikasi Sikap dan Ketahanan Bahasa}

Model Sikap Bahasa (Baker 1992) mengandungi tiga komponen utama, iaitu kognitif, afektif dan konatif (rujuk Rajah 1). Komponen kognitif mewakili ideologi, pemikiran dan kepercayaan penutur, manakala afektif merujuk kepada emosi dan perasaan penutur terhadap objek atau entiti (termasuk bahasa, dialek atau variasi bahasa). Komponen konatif pula melibatkan pelan tindakan penutur berdasarkan pengiktirafan mereka terhadap bahasa dan sebagai pelengkap kepada dua komponen awal. Hal ini termasuklah niat, tingkah laku dan perancangan penutur sama ada untuk menerima atau menolak sebarang kemungkinan yang melibatkan bahasa, dialek atau aksen. Kecenderungan atau prejudis penutur terhadap sesuatu bahasa boleh menghasilkan tindak balas positif atau negatif, sekali gus menentukan tingkah laku linguistik semasa dan prospek bahasa tersebut (Baker 1992).

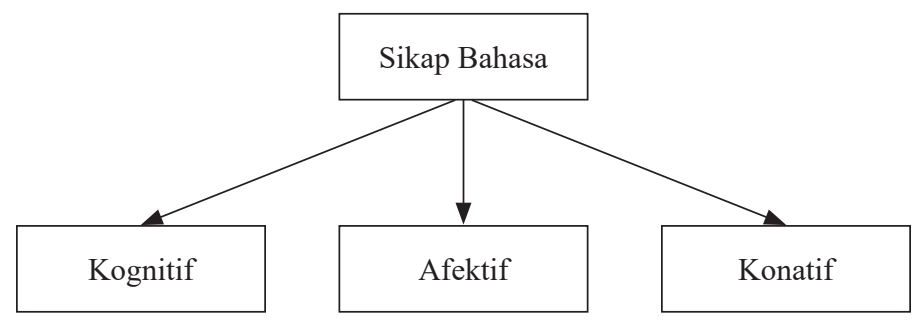

Rajah 1. Model Sikap Bahasa (terjemahan penulis) Sumber: Baker (1992)

Kerangka teori seterusnya lazim digunakan oleh Ethnologue ${ }^{1}$ secara meluas. Ethnologue merupakan sebuah portal rujukan berasaskan web dan katalog keberdayaan bahasa-bahasa dunia berdasarkan penyelidikan daripada ribuan penyelidik dan pakar bahasa. Penaung utama Ethnologue, Lewis dan Simons 
mengubah suai model GIDS asal iaitu Skala Penilaian Gangguan Antara Generasi (Graded Intergenerational Transmission Disruption Scale) gubalan Fishman (1991) dan menamakannya EGIDS yang dilengkapi dengan skala yang mempunyai 13 tahap untuk menganalisis bilangan penutur, penggunaan bahasa, taraf bahasa, selain mentafsir daya hidup bahasa dan penyebaran bahasa serta gangguan antara generasi menurut tindak balas institusi-institusi tertentu. Tahap keberdayaan bahasa dalam skala 0 sehingga 6 a dianggap selamat, sementara tahap keberdayaan bahasa pada skala 6b sehingga 10 dianggap terancam (berdasarkan Jadual 1). Dalam hal ini, EGIDS digunakan untuk mengkaji semula daya hidup bahasa Melayu di Brunei berdasarkan maklum balas para responden kajian dan wacana profesional. EGIDS lazim digunakan oleh para penyelidik kerana dianggap sebagai salah satu instrumen penilaian paling berpengaruh dalam kajian-kajian melibatkan keberdayaan bahasa (Dwyer 2011).

Jadual 1. Model EGIDS bagi analisis kepupusan bahasa (terjemahan penulis)

\begin{tabular}{|c|c|c|c|}
\hline \multicolumn{4}{|c|}{ EGIDS } \\
\hline Skala & Label & Deskripsi & UNESCO \\
\hline 0 & Antarabangsa & $\begin{array}{l}\text { Bahasa ini digunakan secara meluas antara } \\
\text { negara dalam perdagangan, pertukaran } \\
\text { maklumat dan dasar-dasar antarabangsa. }\end{array}$ & Selamat \\
\hline 1 & Nasional & $\begin{array}{l}\text { Bahasa ini digunakan dalam sektor pendidikan, } \\
\text { pekerjaan, media massa dan kerajaan pada } \\
\text { peringkat kebangsaan. }\end{array}$ & Selamat \\
\hline 2 & Serantau & $\begin{array}{l}\text { Bahasa ini digunakan dalam sektor pendidikan, } \\
\text { pekerjaan, media massa dan kerajaan dalam } \\
\text { wilayah yang diiktiraf secara rasmi di sesebuah } \\
\text { negara. }\end{array}$ & Selamat \\
\hline 3 & $\begin{array}{l}\text { Komunikasi } \\
\text { luas }\end{array}$ & $\begin{array}{l}\text { Bahasa ini digunakan tanpa status rasmi dalam } \\
\text { sektor pekerjaan dan media massa untuk } \\
\text { mengatasi perbezaan bahasa rentas rantau. }\end{array}$ & Selamat \\
\hline 4 & Pendidikan & $\begin{array}{l}\text { Bahasa ini bertenaga dan kemahiran literasi } \\
\text { bahasa ini dilestarikan melalui sistem } \\
\text { pendidikan awam. }\end{array}$ & Selamat \\
\hline 5 & Membangun & $\begin{array}{l}\text { Bahasa ini bertenaga dan digunakan secara } \\
\text { berkesan dalam bentuk tulisan dalam kalangan } \\
\text { masyarakat, walaupun kemahiran literasi belum } \\
\text { pada tahap mapan. }\end{array}$ & Selamat \\
\hline $6 a$ & Bertenaga & $\begin{array}{l}\text { Bahasa digunakan secara lisan oleh semua } \\
\text { generasi dan lazimnya dipelajari oleh kanak- } \\
\text { kanak sebagai bahasa pertama. }\end{array}$ & Selamat \\
\hline
\end{tabular}


Jadual 1. (sambungan)

\begin{tabular}{|c|c|c|c|}
\hline \multicolumn{4}{|c|}{ EGIDS } \\
\hline Skala & Label & Deskripsi & UNESCO \\
\hline $6 b$ & Terancam & $\begin{array}{l}\text { Bahasa ini masih digunakan secara lisan oleh } \\
\text { semua generasi, namun terdapat ancaman } \\
\text { yang signifikan terhadap tahap kemapanan, } \\
\text { terutamanya gangguan pemindahan antara } \\
\text { generasi oleh sebahagian besar generasi ibu bapa. }\end{array}$ & Terancam \\
\hline 7 & Peralihan & $\begin{array}{l}\text { Generasi ibu bapa boleh menggunakan bahasa ini } \\
\text { sesama mereka tetapi tidak menyampaikannya } \\
\text { kepada anak-anak mereka. }\end{array}$ & $\begin{array}{c}\text { Amat } \\
\text { terancam }\end{array}$ \\
\hline $8 \mathrm{a}$ & Moribun/Nazak & $\begin{array}{l}\text { Golongan penutur yang aktif bagi bahasa ini } \\
\text { hanya dalam kalangan generasi nenek. }\end{array}$ & $\begin{array}{l}\text { Sangat } \\
\text { terancam }\end{array}$ \\
\hline $8 b$ & $\begin{array}{l}\text { Hampir } \\
\text { pupus }\end{array}$ & $\begin{array}{l}\text { Golongan penutur bahasa yang tinggal } \\
\text { adalah warga tua dan peluang mereka untuk } \\
\text { menggunakan bahasa ini adalah terhad. }\end{array}$ & $\begin{array}{l}\text { Terlalu } \\
\text { terancam }\end{array}$ \\
\hline 9 & Tidak aktif & $\begin{array}{l}\text { Tiada penutur yang mahir dalam bahasa } \\
\text { ini, namun penggunaannya secara simbolik } \\
\text { dipraktikkan sebagai peringatan terhadap identiti } \\
\text { warisan bagi masyarakat etnik. }\end{array}$ & Pupus \\
\hline 10 & Pupus & $\begin{array}{l}\text { Tiada penutur yang mengekalkan identiti etnik } \\
\text { berkaitan dengan bahasa ini, walaupun untuk } \\
\text { tujuan simbolik. }\end{array}$ & Pupus \\
\hline
\end{tabular}

Model LVE yang digubal oleh UNESCO (2011) juga digunakan untuk mengatasi kekurangan yang terdapat dalam penilaian EGIDS, khususnya dalam menganalisis semula keberdayaan bahasa Melayu dari perspektif sikap bahasa. LVE mempunyai sembilan komponen penting dalam proses analitikal keberdayaan dan kepupusan bahasa, namun kajian ini hanya memberi tumpuan kepada dua komponen iaitu: (1) Sikap masyarakat terhadap bahasa mereka (community members' attitudes towards their own language) dan (2) Sikap dasar kerajaan dan institusi bahasa, termasuk status rasmi dan penggunaan bahasa (governmental and institutional language attitudes and policies, including official status and use) (UNESCO 2003, 14). Kedua-dua komponen ini digunakan untuk mentafsir keberdayaan bahasa Melayu dalam kalangan penutur asli Melayu berdasarkan maklum balas sikap bahasa responden dengan mengaplikasi rangka kerja yang relevan dan bukan hanya berdasarkan tanggapan positif atau negatif terhadap bahasa. Kedua-dua komponen ini juga dianggap sangat penting dan berkaitan dengan objektif dan fokus kajian. 


\section{Prestasi Bahasa Melayu di Negara Brunei Darussalam}

\section{Sikap terhadap bahasa Melayu dalam kalangan penutur dwibahasa di Brunei}

Sikap terhadap bahasa Melayu Brunei adalah positif dalam ketiga-tiga komponen. Bagi komponen kognitif, walaupun bahasa vernakular seperti bahasa Melayu Brunei lazimnya dianggap kurang berprestij dan tidak formal, namun bahasa ini tetap menjadi pilihan utama dalam komunikasi harian dan dalam urusan rasmi. Berdasarkan hasil ujian tindak balas subjek, sentimen terhadap bahasa Melayu Brunei juga seiring dengan bahasa Melayu standard dan bahasa Inggeris dari aspek profesionalisme kerana bahasa Melayu Brunei juga dikaitkan secara positif dengan ciri-ciri "berpendidikan", "cerdik" dan "berkebolehan". Jadual 2 memaparkan rumusan hasil ujian tindak balas subjek terhadap empat rakaman bagi empat variasi bahasa. Secara purata, penilaian positif ditandai dengan hijau dan penilaian neutral ditandai dengan kuning serta penilaian negatif ditandai dengan merah. Dalam hal ini, bahasa Melayu Brunei diterima baik walaupun dalam situasi formal kerana terdapatnya toleransi yang tinggi dalam ekologi keanekabahasaan di Brunei.

Jadual 2. Perbandingan hasil ujian tindak balas dalam domain formal dan solidariti

\begin{tabular}{|c|c|c|c|c|c|}
\hline Domain & Sifat & $\begin{array}{c}\text { Bahasa } \\
\text { Melayu } \\
\text { Brunei } \\
\text { (Rakaman A) }\end{array}$ & $\begin{array}{c}\text { Bahasa } \\
\text { Melayu } \\
\text { standard } \\
\text { (Rakaman B) }\end{array}$ & $\begin{array}{c}\text { Bahasa } \\
\text { Inggeris } \\
(\text { Rakaman C) }\end{array}$ & $\begin{array}{c}\text { Alih kod } \\
\text { bahasa Melayu } \\
\text { dan bahasa } \\
\text { Inggeris } \\
\text { (Rakaman D) }\end{array}$ \\
\hline \multirow{6}{*}{ 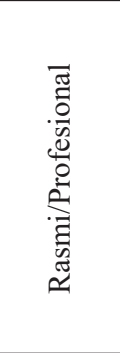 } & Berpendidikan & 3.54 & 4.19 & 4.48 & 3.15 \\
\hline & Cerdik & 3.56 & 3.96 & 4.21 & 3.20 \\
\hline & Berkebolehan & 3.52 & 3.91 & 4.22 & 3.09 \\
\hline & Berdisiplin & 3.41 & 4.04 & 4.15 & 2.63 \\
\hline & Dominan & 3.33 & 3.73 & 3.90 & 2.85 \\
\hline & $\begin{array}{l}\text { Berstatus sosial } \\
\text { tinggi }\end{array}$ & 3.00 & 3.67 & 4.04 & 2.83 \\
\hline \multirow{7}{*}{ 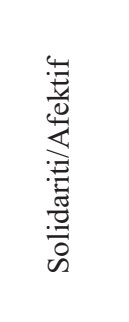 } & Mudah & 3.95 & 4.02 & 3.97 & 3.32 \\
\hline & Indah & 3.49 & 3.70 & 3.89 & 2.88 \\
\hline & Bergaya & 3.34 & 3.01 & 3.88 & 3.06 \\
\hline & Berkeyakinan & 3.99 & 3.83 & 4.23 & 3.36 \\
\hline & Ramah & 4.30 & 3.38 & 3.81 & 3.75 \\
\hline & Dipercayai & 3.54 & 3.71 & 3.93 & 3.13 \\
\hline & Emosional & 3.42 & 2.43 & 3.22 & 3.20 \\
\hline
\end{tabular}


Bahasa Melayu Brunei jelas digemari dalam dimensi afektif kerana dianggap sebagai simbol identiti dan penanda perpaduan orang Melayu Brunei, selain merupakan bahasa pertama bagi majoriti responden. Penemuan kaji selidik mendapati 153 daripada $200(76.5 \%)$ responden menyatakan bahasa Melayu Brunei merupakan bahasa pertama mereka dan tiada responden menyatakan bahasa Inggeris sebagai bahasa pertama. Pengukuhan bahasa Melayu Brunei ini turut dilihat melalui kecenderungan responden untuk memilih bahasa tersebut sebagai bahasa komunikasi ideal di rumah (rujuk Jadual 3) dan juga dalam domain pendidikan dan pekerjaan (rujuk Rajah 2). Selain itu, 188 daripada 200 (94\%) responden juga menyatakan bahasa Melayu Brunei sebagai simbol identiti kerana ia merupakan bahasa ibunda dan bahasa utama yang digunakan oleh majoriti rakyat Brunei dalam kehidupan seharian.

Jadual 3. Pilihan bahasa komunikasi di rumah

\begin{tabular}{lcr}
\hline Bahasa komunikasi di rumah & $\begin{array}{c}\text { Bilangan responden } \\
(\boldsymbol{n}=\mathbf{2 0 0})\end{array}$ & Peratus \\
\hline Bahasa Melayu Brunei & 158 & 79.0 \\
Bahasa Melayu standard & 5 & 2.5 \\
Bahasa Inggeris & 4 & 2.0 \\
Bahasa Melayu Brunei dan bahasa Inggeris & 27 & 13.5 \\
Lain-lain & 6 & 3.0 \\
\hline
\end{tabular}

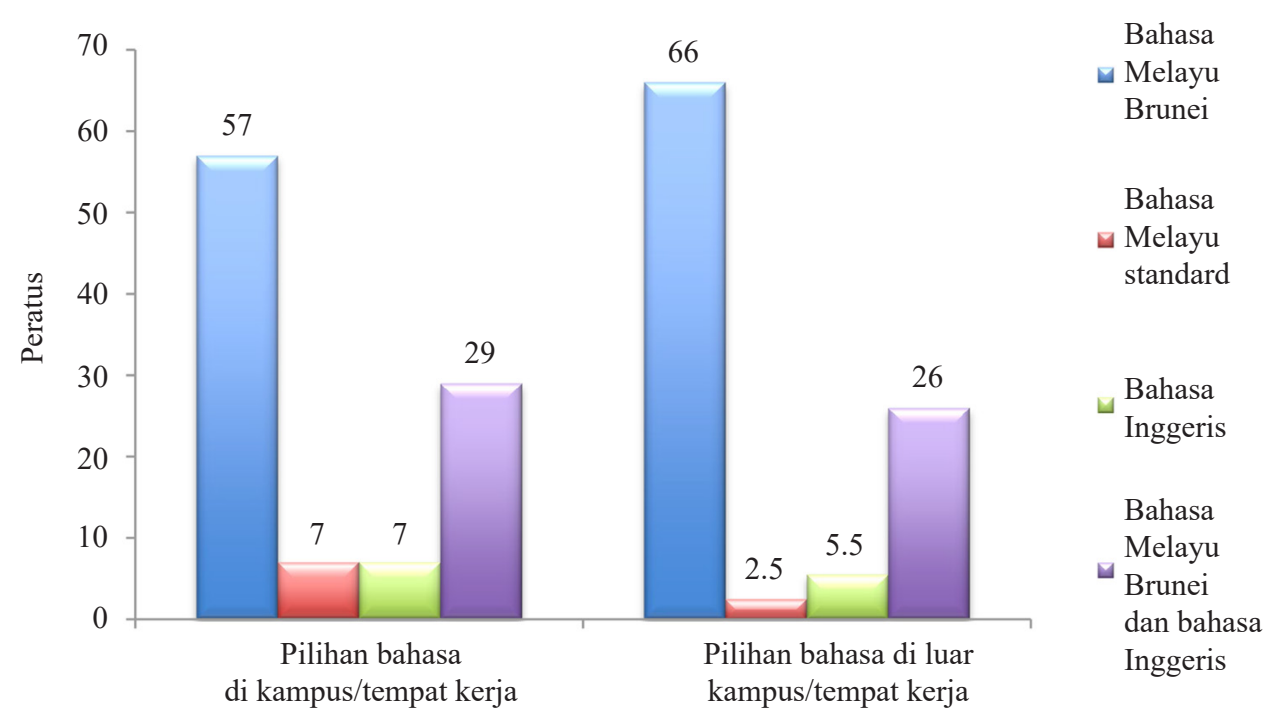

Rajah 2. Pilihan bahasa komunikasi di dalam dan di luar kampus/tempat kerja 
Kewujudan dimensi konatif jelas terbukti melalui penggunaan bahasa tersebut dalam situasi formal dan informal serta sebagai bahasa pertama atau ibunda merentasi generasi penutur. Hal ini dikuatkan lagi dengan aspirasi sebahagian besar responden untuk mewariskan bahasa Melayu Brunei kepada generasi baharu. Melalui dapatan kajian, sebanyak 188 responden (94\%) bersetuju mewariskan bahasa Melayu Brunei sebagai bahasa pertama anak-anak mereka. Hal ini kerana mereka menyedari bahawa penyebaran bahasa Melayu Brunei antara generasi akan menjamin penggunaan dan pelestarian bahasa Melayu Brunei, sekali gus mempertahankan kepentingan bahasa tersebut di samping bahasa-bahasa antarabangsa seperti bahasa Inggeris. Oleh yang demikian, sikap positif terhadap bahasa Melayu Brunei dalam ketiga-tiga komponen boleh dianggap sebagai kongruen dan konsisten, sekali gus berpotensi menjamin keberdayaan bahasa Melayu Brunei.

Kecenderungan positif terhadap bahasa Melayu standard lebih tertumpu pada komponen kognitif kerana lebih kerap digunakan dalam situasi rasmi atau formal dan media profesional. Sikap terhadap bahasa Melayu standard dalam aspek afektif daripada penilaian kendiri pula menunjukkan ketiadaan nilai emotif yang jelas kerana sebahagian besar responden menyatakan bahasa ini khusus digunakan bagi keperluan formaliti dan profesionalisme, malah dianggap "janggal" untuk digunakan sebagai kod komunikasi seharian. Perihal yang sama turut dilihat dalam hasil ujian tindak balas subjek yang menunjukkan penilaian negatif pada sifat emosional (rujuk Jadual 2). Ketiadaan nilai emotif terhadap bahasa Melayu standard lazimnya terjadi memandangkan bahasa ini tidak digunakan sebagai bahasa pertama dan bukan pilihan utama sebagai kod komunikasi antara generasi atau silang etnik di Brunei (Clynes dan Deterding 2011; Fatimah dan Najib 2015; Martin 1996). Menariknya, dapatan ujian tindak balas subjek terhadap sikap bahasa tersirat (covert) menunjukkan bahasa Melayu standard mempunyai nilai afektif positif hampir sejajar dengan nilai yang ada dalam bahasa Melayu Brunei (rujuk Jadual 2). Akan tetapi, dengan perincian khusus bahawa bahasa Melayu standard dianggap lebih "mudah" (easy), "indah" (beautiful) dan "boleh dipercayai" (reliable) daripada bahasa Melayu Brunei. Hal ini turut ditopang menerusi penggunaan bahasa berkenaan dalam konteks yang formal oleh para pegawai atasan yang sekali gus menunjukkan perpaduan dan setiakawan terhadap bahasa tersebut, walaupun berada dalam latar antarabangsa (Najib dan McLellan 2021).

Bagi konteks Brunei, bahasa Melayu standard lazimnya tidak digunakan sebagai bahasa pertama dalam komunikasi antara generasi (Najib 2020) dan keadaan tersebut turut dikesan melalui maklum balas responden dalam kajian ini. Aspirasi penyebaran bahasa Melayu standard antara generasi sebagai bahasa 
pertama boleh dianggap kurang relevan memandangkan bahasa ini hanya digunakan khusus bagi tujuan rasmi dan akademik (Clynes dan Deterding 2011), selain hanya digunakan untuk memaksimumkan pemahaman ketika berkomukasi dengan penutur dari Malaysia dan Indonesia, dan dengan penutur bukan Melayu yang memahami bahasa Melayu (Martin dan Poedjosoedarmo 1996). Noor Azam Haji Othman (pers. comm., 5 April 2017) mendakwa orang Melayu Brunei tidak berkomunikasi sesama sendiri menggunakan bahasa Melayu standard kerana bimbang “...sounding more like Malaysian or Indonesian" (dianggap sebagai penutur dari Malaysia atau Indonesia), sekali gus mewujudkan isu jati diri.

Sikap positif terhadap bahasa Inggeris jelas menonjol dalam komponen kognitif seiring dengan kedudukan bahasa tersebut sebagai bahasa antarabangsa yang juga selalu dikaitkan dengan prestij pendidikan, kebijaksanaan dan berkeupayaan menyampaikan banyak perkara. Hal ini dapat ditinjau melalui penilaian kendiri responden kajian yang mendakwa pendidikan dalam bahasa Inggeris adalah sangat berharga bagi pengguna bahasa tersebut (rujuk Rajah 3).

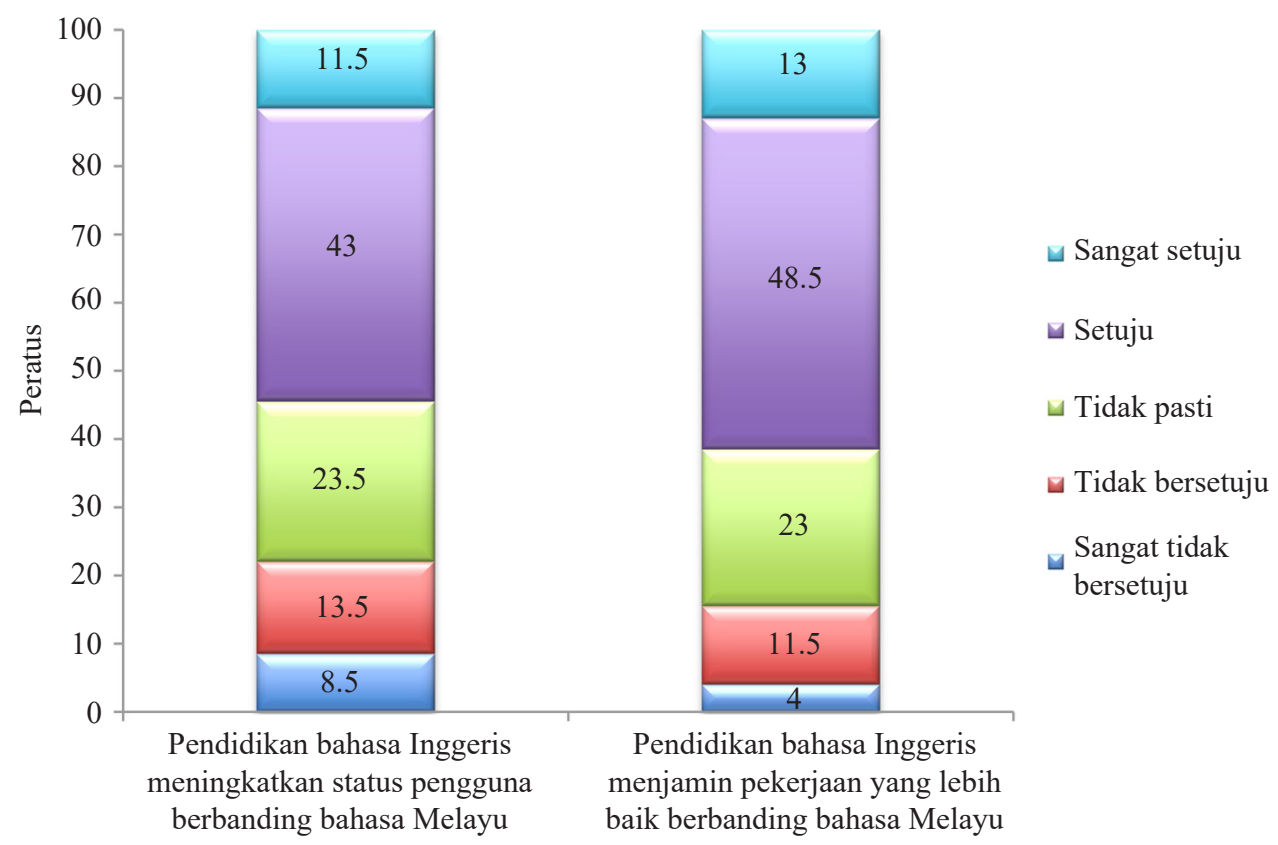

Rajah 3. Prospek bahasa Melayu dan bahasa Inggeris dalam alam pendidikan/pekerjaan 
Seiringan dengan ini, berdasarkan ujian tindak balas subjek, sikap positif dalaman terhadap bahasa Inggeris dalam domain rasmi atau profesionalisme juga sangat tinggi (rujuk Jadual 2). Dapatan ini menunjukkan betapa pentingnya bahasa Inggeris bagi tujuan pendidikan dan pekerjaan. Hal ini sejajar dengan dapatan kajian Ożóg (1996) dan Saxena (2006) yang menghubungkan bahasa Inggeris dengan pengetahuan moden, taraf pendidikan dan kejayaan seseorang. Keadaan ini menggambarkan taraf bahasa Inggeris di Brunei. Hal ini dapat dilihat dari segi penggunaan bahasa tersebut yang begitu meluas dalam sektor pendidikan dan pekerjaan serta perhubungan antarabangsa (Ishamina dan Deterding 2017; Jones 1996). Dengan taraf seperti ini, bahasa Inggeris memperlihatkan peranan yang serupa dengan bahasa Melayu (Wood et al. 2001).

Sikap positif terhadap bahasa Inggeris tidak menjejaskan tanggapan responden terhadap bahasa Melayu. Seperti yang dijelaskan sebelum ini, dapatan kajian menunjukkan majoriti responden masih memilih bahasa Melayu sebagai identiti kebangsaan dan simbol etnik dan budaya, walaupun mereka turut mengakui kepentingan bahasa Inggeris. Kajian ini turut mendapati penggunaan bahasa Melayu Brunei yang meluas di rumah dan di kampus atau di tempat kerja (rujuk Jadual 3 dan Rajah 2). Keadaan ini menunjukkan bahawa penilaian afektif terhadap bahasa Inggeris mungkin tidak konsisten dengan sikap positif terhadap bahasa Melayu Brunei. Namun demikian, tidak dapat dinafikan bahawa kepentingan bahasa Inggeris adalah tinggi dan bersifat instrumental.

Walaupun demikian, masih tidak dinafikan terdapat pertalian antara bahasa Melayu standard dengan bahasa Melayu Brunei sebagai identiti profesionalisme dalam kalangan orang Melayu Brunei. Bagi bahasa Melayu Brunei, keadaan tersebut dapat dikesan melalui penggunaan bahasa tersebut dalam situasi formal merentasi domain informal, sementara bahasa Melayu standard pula diperakui oleh status dan penggunaan bahasa berkenaan bagi majoriti responden, seperti yang turut dikesan dalam kalangan belia melalui kajian Najib (2020) dan Najib dan McLellan (2021). Kesedaran yang tinggi terhadap bahasa Melayu lahir dari penghayatan Melayu Islam beraja (MIB) sebagai falsafah negara yang berdaya membangkitkan kesedaran kebangsaan (Najib 2020; Saxena 2006; Saxena dan Sercombe 2002). Perihal ini turut diakui oleh responden dan pakarpakar bahasa yang terlibat dalam kajian ini dalam pernyataan-pernyataan berikut:

Adanya kepemimpinan negara yang berpusat kepada sultan dan perlembagaan nasional serta dasar bahasa dan ideologi MIB, situasi bahasa Melayu di Brunei lebih stabil berbanding dengan negara-negara Melayu yang lain, walaupun terdapat tekanan dwibahasa di negara 
ini. Oleh itu, Brunei juga selalu menjadi pusat rujukan bagi guruguru Melayu dari negara-negara jiran mengenai implementasi amalan kedwibahasaan di negara ini. (Aminah Momin, pers. comm., 19 Februari 2017)

Malay maintenance in Brunei will continue to exist as both Malay and English are used according to their needs and situations. For instance, standard Malay is used as official written language in professional setting and records, while the vernacular Brunei Malay and English are used in spoken interaction. The strong Malay maintenance is due to the stable language policy in both national constitution and education system enforced in the sultanate. (Noor Azam Haji Othman, pers. comm., 5 April 2017)

[Ketahanan bahasa Melayu di Brunei akan terus wujud kerana bahasa Melayu dan bahasa Inggeris digunakan mengikut keperluan dan situasi. Contohnya, bahasa Melayu standard digunakan sebagai bahasa penulisan rasmi dalam latar profesional dan dokumentasi, sementara bahasa Melayu Brunei dan bahasa Inggeris digunakan dalam interaksi lisan. Ketahanan bahasa Melayu yang kuat juga disebabkan oleh dasar bahasa yang stabil dalam perlembagaan negara dan sistem pendidikan yang dikuatkuasakan di Brunei.]

The situation in Brunei is very much tied to the MIB principle and is state prerogative. It is interesting to note that Brunei tied their language policy to certain principles. (Mohamed Pitchay Gani Aziz, pers. comm., 25 Mac 2017)

[Situasi (bahasa Melayu) di Brunei sangat berkait dengan prinsip MIB dan hak asasi negara. Sangat menarik untuk diperhatikan bahawa Brunei mengaitkan dasar bahasa mereka dengan prinsip-prinsip tertentu.]

Perkara yang sama juga boleh dikesan melalui analisis kemahiran berbahasa melibatkan penelitian keputusan peperiksaan General Certificate of Education Ordinary Level (BGCE 'O' Level) bagi subjek Bahasa Melayu (1201) dan Bahasa Inggeris (English Language) (1120) bagi sesi November dari tahun 2010 sehingga 2016. Kecemerlangan dalam kedua-dua subjek diperlukan bagi menjamin akses kepada biasiswa kerajaan dan peluang pekerjaan yang baik. Berdasarkan rumusan analisis, kadar pendaftaran bagi subjek 1201 adalah lebih banyak berbanding subjek 1120, selain jumlah keputusan cemerlang dan lulus dalam subjek 1201 juga lebih tinggi berbanding subjek 1120. Sungguhpun demikian, jumlah keputusan cemerlang dan lulus dalam subjek 1120 juga didapati semakin meningkat. 
Berdasarkan analisis perbandingan kedua-dua set keputusan peperiksaan BGCE 'O' Level subjek 1201 dan 1120 dari tahun 2010 ke 2016 menggunakan ujian statistik chi-kuasa dua (chi-square statistical test) mendapati tiada perkaitan langsung antara kecemerlangan dan kegagalan dalam subjek 1201 dan 1120, sekali gus memberi indikator bahawa setiap pelajar atau calon peperiksaan boleh cemerlang dalam kedua-dua subjek. Perihal ini turut diperakui oleh lima pegawai pendidikan yang terlibat secara langsung dalam pengajaran kedua-dua subjek. Seorang pegawai pendidikan bahasa Melayu mendakwa bahawa keduaduanya melibatkan kreativiti, sekiranya pelajar boleh bertutur dan menulis dalam bahasa Inggeris, mereka juga boleh menggunakan bahasa Melayu dengan fasih. Berdasarkan pengalaman yang sama, pegawai-pegawai pendidik yang lain juga bersetuju dengan sentimen yang sama kerana mereka juga merupakan penutur dwibahasa yang kompeten. Dapatan ini menunjukkan bahawa kemahiran berbahasa dalam bahasa Melayu standard masih kukuh, selain turut memaparkan kebolehan berbahasa secara dwibahasa juga semakin meningkat.

Kajian ini juga mendapati bahawa para responden menunjukkan sikap yang lebih neutral terhadap penggunaan alih kod antara bahasa Melayu dan bahasa Inggeris (rujuk Jadual 2). Mereka mengakui menggunakannya dalam perbualan harian, khususnya dalam konteks informal. Sikap bahasa yang tidak kongruen ini berkemungkinan berpunca daripada stigma terhadap fenomena alih kod yang selalu dianggap sebagai "salah" dan "tidak bermoral", walaupun lazimnya dipraktikkan dalam persekitaran dwibahasa atau berbilang bahasa (Husni 2009; McLellan 2005; Najib 2020). Walaupun begitu, perkara ini tidak menjejaskan kebolehan penutur dalam menggunakan bahasa Melayu standard dan bahasa Inggeris mengikut keperluan kerana mereka juga sedar akan peranan dan tanggungjawab mereka sebagai penutur terhadap bahasa-bahasa tersebut. Perihal ini turut diakui oleh pakar-pakar bahasa Melayu di nusantara dan antarabangsa sekali gus mengukuhkan kesahihan bagi kestabilan kedwibahasaan bahasa Melayu dan bahasa Inggeris di Brunei dan juga di alam Melayu.

Bahasa Melayu dan bahasa Inggeris saling melengkapi, tetapi kedudukan dan fungsi bahasa Melayu perlu lebih tinggi dan luas. Bahasa Melayu asas jati diri, bahasa Inggeris menjadi asas nilai kerana dari dahulu bangsa Melayu di alam Melayu mendapat kekuatan juga daripada bahasa-bahasa asing, seperti Sanskrit, Arab, Parsi, Tamil, Cina, Portugis dan Belanda. (Awang Sariyan, pers. comm., 9 Oktober 2017)

Keadaan dwibahasa lebih stabil di Brunei dan kewujudan variasi bahasa Melayu yang lain turut menyumbang kepada ketahanan bahasa Melayu... Bahasa Melayu ada kewujudannya dan caranya tersendiri, sudah lama pun. Seperti Inggeris pun ada perancangan dari dulu ada 
perancangan untuk memperkembangkannya. Bahasa [Melayu] kita sangat canggih dalam bahasa oral, contohnya dalam penceritaan sastera yang dahulu. (Muhammad Haji Saleh, pers. comm., 9 Ogos 2017)

Saya berkomunikasi menggunakan sistem pertuturan mengikut keadaan, baiklah, saya berbahasa Inggeris apabila keadaan memerlukan saya menggunakan bahasa Inggeris, apabila keadaan sesuai untuk saya bertutur menggunakan dialek [Melayu] Kedah di rumah, saya akan bertutur dalam dialek [Melayu] Kedah, supaya anak-anak tahu dialek [Melayu] Kedah...tiada pertandingan [antara dua bahasa], dan bahkan antara orang Melayu, mereka mengatakan bahawa mereka tidak melagakan bahasa Melayu dan Inggeris, mereka hanya berusaha untuk menjadi sebahagian daripada sistem dan boleh bertutur dalam keduadua bahasa untuk bergerak maju dalam masyarakat - jadi apa salahnya? (Asmah Haji Omar, pers. comm., 21 September 2016)

Berkait dengan kemelayuan dan keindonesiaan, kehadiran bahasa Inggeris, yakni yang telah menjadi lingua franca yang mengglobal, bukanlah suatu ancaman, melainkan sebagai sarana bagi orang Melayu/Indonesia untuk dapat berkomunikasi dengan anggota lain dari masyarakat dunia. Dengan kata lain, bahasa Inggeris berperan memersatukan orang Melayu/Indonesia dengan elemen-elemen lain yang menjadi pembentuk masyarakat dunia atau masyarakat global. (Fauzi Syamsuar, pers. comm., 3 November 2017)

Ya, memang ada [kewujudan bersama kedua-dua bahasa]. Begitu banyak aspek budaya tertentu hanya dapat digambarkan dalam bahasa Melayu, dan fenomena ini memerlukan kedua-dua bahasa itu wujud. (Fuad Abdul Hamied, pers. comm., 6 Februari 2018)

I would not say Malay is endangered as the majority of people for instance in Malaysia is Malay, and it is used as a strong lingua franca, especially in Brunei and Borneo with Sabah and Sarawak, in Indonesia of course. If we include Malay with bahasa Indonesia, because they are basically of the same language, apart from the small differences, I would not say they are endangered. (Paolo Coluzzi, pers. comm., 29 Mac 2017)

[Saya tidak akan mengatakan bahasa Melayu terancam kerana majoriti rakyat misalnya di Malaysia adalah orang Melayu, dan bahasa ini digunakan sebagai bahasa lingua franca secara meluas, terutamanya di Brunei dan di Borneo dengan Sabah dan Sarawak, seterusnya di Indonesia. Sekiranya kita merangkumkan bahasa Melayu dengan bahasa Indonesia, kerana pada dasarnya mereka menggunakan bahasa yang sama selain daripada perbezaan yang kecil, saya tidak akan mengatakan bahawa mereka (bahasa Melayu/Indonesia) terancam.] 
Malay is not being threatened at all, I would say Malay is being strong, not threaten at all, all languages are in contact and influence each other, clearly if you have bilingual, if Malay can speak bilingual Malay and English, they are very likely to codemix because they can...there is always language contact and code-mixing and it is not threatening the Malay. (Andy Kirkpatrick, pers. comm., 22 Jun 2017)

[bahasa Melayu tidak terancam, saya akan mengatakan (ketahanan) bahasa Melayu kuat, tidak terancam sama sekali, semua bahasa saling berhubungan dan saling mempengaruhi, jelas terdapat situasi kedwibahasaan, sekiranya orang Melayu boleh bertutur dwibahasa dalam bahasa Melayu dan bahasa Inggeris, mereka akan cenderung untuk beralih kod kerana mereka berkebolehan...memang hubungan antara bahasa dan percampuran kod selalu ada dan keadaan ini tidak mengancam bahasa Melayu.]

Berdasarkan data yang diperoleh melalui metode penyelidikan secara triangulasi melibatkan 200 responden Melayu, pakar-pakar bahasa Melayu dan antarabangsa, dan analisis dokumentasi, kajian ini mendapati bahawa interaksi bahasa Melayu dan bahasa Inggeris di Brunei dari aspek sosiolinguistik menunjukkan tiada pertelingkahan dalam kontak bahasa dan tiada unsurunsur kedwibahasaan subtraktif (substractive bilingualism), malah ketiga-tiga bahasa Melayu Brunei, bahasa Melayu standard dan bahasa Inggeris saling melengkapi berdasarkan keperluan dan situasi penggunaan serta audiens (lawan tutur).

\section{Ketahanan Bahasa Melayu Standard dan Bahasa Melayu Brunei}

Berdasarkan analisis kriteria-kriteria penting EGIDS, termasuk pengiktirafan rasmi dan praktikal bahasa dalam sektor pendidikan, pekerjaan, media massa dan kerajaan, tahap keberdayaan bahasa Melayu standard di Brunei diklasifikasikan dalam Tahap 1 (Nasional). Bahasa Melayu standard diiktiraf dalam pelbagai domain formal, termasuk dalam penggunaan pentadbiran dan urusan rasmi kerajaan, selain turut menerima sokongan institusi kerajaan dan dipantau melalui usaha-usaha standardisasi oleh kerajaan dan Dewan Bahasa dan Pustaka (DBP). Sikap positif terhadap bahasa Melayu standard dan kesedaran terhadap kepentingannya dalam domain rasmi atau profesional melayakkan pengklasifikasian bahasa Melayu standard dalam spektrum bahasa yang selamat (rujuk Jadual 4). 
Jadual 4. Analisis ketahanan bahasa Melayu standard menggunakan EGIDS

\begin{tabular}{|c|c|c|c|}
\hline Bahasa & $\begin{array}{l}\text { Skala } \\
\text { EGIDS }\end{array}$ & Domain & Situasi dan deskripsi bahasa \\
\hline \multirow[t]{14}{*}{$\begin{array}{l}\text { Bahasa } \\
\text { Melayu } \\
\text { standard }\end{array}$} & $\begin{array}{l}\text { Tahap } 1 \\
\text { (Nasional) }\end{array}$ & Kerajaan & $\begin{array}{l}\text { 1. Diiktiraf sebagai bahasa rasmi negara } \\
\text { berdasarkan kanun (Perkara } 82 \text { (1) } \\
\text { Perlembagaan Brunei 1959). }\end{array}$ \\
\hline & & & $\begin{array}{l}\text { 2. Diiktiraf dan digunakan sebagai bahasa rasmi } \\
\text { dalam pentadbiran dan dokumentasi. }\end{array}$ \\
\hline & & & $\begin{array}{l}\text { 3. Diiktiraf sebagai bahasa identiti orang Melayu } \\
\text { Brunei melalui falsafah kebangsaan MIB. }\end{array}$ \\
\hline & & & $\begin{array}{l}\text { 4. Diperlukan kemahirannya dalam memohon } \\
\text { kewarganegaraan Brunei (rujuk Bab } 15 \text { (5) } \\
\text { Akta Pendaftaran Kebangsaan Brunei 1961). }\end{array}$ \\
\hline & & & $\begin{array}{l}\text { 5. Digunakan sebagai bahasa perantaraan rasmi } \\
\text { bagi nyanyian lagu kebangsaan. }\end{array}$ \\
\hline & & & $\begin{array}{l}\text { 6. Digunakan dalam proses pengislaman di Pusat } \\
\text { Da'wah Islamiah. }\end{array}$ \\
\hline & & & $\begin{array}{l}\text { 7. Digunakan sebagai bahasa rasmi utama di } \\
\text { papan tanda umum dalam Peraturan } 3 \text { (4) } \\
\text { (Peraturan Kawalan Bangunan 2016). }\end{array}$ \\
\hline & & & $\begin{array}{l}\text { 8. Dipantau dan dipelihara oleh DBP dan } \\
\text { Majlis Bahasa Brunei-Indonesia-Malaysia } \\
\text { (MABBIM) (negara anggota). }\end{array}$ \\
\hline & & Pendidikan & $\begin{array}{l}\text { 1. Diiktiraf sebagai bahasa perantaraan dalam } \\
\text { dasar pendidikan dwibahasa negara. }\end{array}$ \\
\hline & & & $\begin{array}{l}\text { 2. Diajar sebagai subjek di semua peringkat } \\
\text { institusi pendidikan. }\end{array}$ \\
\hline & & & $\begin{array}{l}\text { 3. Digunakan sebagai bahasa rasmi dalam } \\
\text { penulisan. }\end{array}$ \\
\hline & & & $\begin{array}{l}\text { 4. Diperlukan kemahirannya untuk mendapatkan } \\
\text { akses kepada biasiswa kerajaan. }\end{array}$ \\
\hline & & Pekerjaan & $\begin{array}{l}\text { 1. Digunakan sebagai bahasa rasmi di tempat } \\
\text { kerja dan dokumentasi (terutamanya sektor } \\
\text { kerajaan). }\end{array}$ \\
\hline & & & $\begin{array}{l}\text { 2. Diperlukan untuk mendapatkan peluang } \\
\text { pekerjaan yang lebih baik. }\end{array}$ \\
\hline
\end{tabular}


Jadual 4. (sambungan)

\begin{tabular}{llll}
\hline Bahasa & $\begin{array}{l}\text { Skala } \\
\text { EGIDS }\end{array}$ & Domain & Situasi dan deskripsi bahasa \\
\hline & Media massa & 1. & $\begin{array}{l}\text { Diiktiraf dan digunakan sebagai bahasa rasmi } \\
\text { media massa kerajaan. }\end{array}$ \\
& 2. $\quad \begin{array}{l}\text { Digunakan sebagai bahasa rasmi dalam } \\
\text { penggunaan awam atau penerbitan dan antara } \\
\end{array}$ & $\begin{array}{l}\text { institusi serta pekeliling. } \\
\text { 3. }\end{array}$ \\
& & $\begin{array}{l}\text { Diiktiraf, disokong dan digunakan secara } \\
\text { rasmi oleh media penyiaran kebangsaan, Radio } \\
\text { Televisyen Brunei. }\end{array}$ \\
& 4. $\quad \begin{array}{l}\text { Digunakan sebagai bahasa utama akhbar } \\
\text { kerajaan rasmi, Pelita Brunei. }\end{array}$ \\
& &
\end{tabular}

Sementara itu, pengklasifikasian terbaik bagi tahap keberdayaan bahasa Melayu Brunei adalah 6a (Bertenaga). Hal ini berikutan permindahan bahasa Melayu Brunei antara generasi yang berterusan sebagai bahasa pertama dan penggunaan bahasa ini yang mendominasi domain keluarga dan sahabat handai. Faktor ini memastikan kemampanan penyampaian lisan dalam keluarga dan di peringkat masyarakat. Penggunaan bahasa Melayu Brunei juga masih utuh sebagai sebahagian daripada simbol identiti dan penanda kebudayaan orang Melayu Brunei. Selain itu, bahasa ini juga digunakan secara meluas sebagai bahasa vernakular merentasi generasi dan etnik Melayu Brunei yang berbeza. Perbandingan diakronik melibatkan penemuan yang dilaporkan oleh Ahmad (1978), Martin (1996), Najib (2020) dan kajian ini menunjukkan bahawa penggunaan, penyampaian dan penyebaran bahasa Melayu Brunei adalah stabil dan selamat. Walaupun perbandingan hasil ketiga-tiga kajian ini tidak melibatkan sampel responden yang sama, namun kecenderungan masyarakat Melayu Brunei untuk menggunakan bahasa Melayu Brunei dari masa ke masa masih ditunjukkan, sekali gus memaparkan bukti bahawa bahasa vernakular tersebut turut dilestari dan digunakan secara meluas. Perbandingan diakronik daripada hasil ketiga-tiga kajian ini turut menunjukkan kestabilan bahasa Melayu Brunei sebagai bahasa pertama dan de facto walaupun Brunei telah menghadapi perubahan dan perkembangan signifikan dari aspek sosio-politikal, termasuklah mencapai kemerdekaan pada tahun 1984, penerapan sistem pendidikan dwibahasa pada tahun 1985 dan SPN-21 pada tahun 2009, dan lebih banyak pendedahan bahasa Inggeris dalam pelbagai domain formal dan informal serta perhubungan antarabangsa. 
Pengklasifikasian bahasa Melayu Brunei pada Tahap 6a dalam EGIDS juga adalah kerana bahasa ini memenuhi sebahagian besar kriteria kemapanan penyampaian lisan (sustainable orality) dalam Model Kemapanan Penggunaan Bahasa FAMED (FAMED Sustainable Language Use Model). FAMED merupakan sebuah model tambahan yang digunakan dalam EGIDS (Lewis dan Simons 2015) yang melakarkan faktor-faktor berikut: (1) Fungsi (Function) - Bahasa Melayu Brunei digunakan secara lisan bagi keperluan komunikasi di rumah dan dalam kalangan masyarakat serta domain-domain lain yang diperlukan, (2) Pemerolehan (Acquisition) - Bahasa Melayu Brunei terus berperanan sebagai bahasa pertama bagi sebahagian besar masyarakat Melayu Brunei, (3) Motivasi (Motivation) - Penutur menyedari peranan bahasa Melayu Brunei dari segi sosial, ekonomi, agama dan sebagai sebahagian daripada identiti, (4) Persekitaran (Environment) - Walaupun bahasa Melayu Brunei tidak diiktiraf secara jelas dalam dokumentasi rasmi, penggunaan variasi informal ini adalah meluas dalam situasi rasmi atau formal memandangkan dasar bahasa kebangsaan juga tidak membatasi kepelbagaian bahasa, seperti yang dinyatakan oleh Noor Azam (2005), dan (5) Penggunaan khusus (Distinct niche) - Penutur berkongsi norma-norma umum dan menggunakan bahasa Melayu Brunei bagi tujuan khusus berdasarkan konteks dan lawan tutur. Bahasa Melayu Brunei juga mempunyai peranan berbeza dengan bahasa-bahasa yang lebih dominan seperti bahasa Melayu standard dan bahasa Inggeris. Kriteria-kriteria ini merupakan bukti kukuh bahawa pelestarian bahasa Melayu Brunei dalam kalangan penuturnya masih lagi kukuh.

Namun demikian, masih terdapat batasan tertentu dalam penggunaan EGIDS (Lewis dan Simon 2010) bagi mentafsir situasi bahasa Melayu Brunei yang telah melampaui had domainnya. Hal ini kerana bahasa Melayu Brunei yang berperanan sebagai bahasa vernakular mula diterima sebagai bahasa de facto yang digunakan seiring dengan bahasa Melayu standard dan bahasa Inggeris dalam sektor pendidikan dan pekerjaan (domain formal), seperti yang didapati daripada hasil pemerhatian kajian ini. Status dan penggunaan bahasa Melayu Brunei yang lebih fleksibel menunjukkan bahawa variasi bahasa ini tidak mudah diklasifikasikan kepada tahap spesifik seperti yang ditetapkan oleh EGIDS kerana berkemungkinan memerlukan lebih daripada satu tahap dalam menerangkan bahasa ini secara menyeluruh. Selain itu, kepentingan bahasa Melayu Brunei dan bahasa Melayu standard dalam penyebaran agama Islam di Brunei seperti yang dijelaskan oleh pegawai perwakilan di Pusat Da'wah Islamiah dan faktor agama Islam yang membantu pelestarian bahasa Melayu juga tidak mudah dijustifikasikan dengan EGIDS. Sungguhpun demikian, dapatan kajian menunjukkan bahawa bahasa Melayu Brunei masih berada 
dalam spektrum bahasa yang selamat dan tidak mudah terancam. Indikator yang digunakan melalui EGIDS dan model FAMED juga menunjukkan bahawa bahasa Melayu Brunei mempunyai ketahanan bahasa yang tinggi.

Bagi melengkapi kekurangan EGIDS yang banyak menumpukan kepada sokongan institusi dan permindahan bahasa, faktor "Sikap masyarakat terhadap bahasa mereka" dalam LVE adalah penting dalam mengkaji sentimen solidariti dan afektif serta cara faktor tersebut mempengaruhi daya hidup bahasa Melayu Brunei dan bahasa Melayu standard. Berdasarkan dapatan kajian, tahap sokongan dan pelestarian kedua-dua bahasa ini adalah selaras dengan kriteria pada Tahap 5, iaitu menunjukkan tahap keberdayaan bahasa yang sangat tinggi (rujuk Jadual 5).

Jadual 5. Tahap dan sikap anggota masyarakat terhadap bahasa mereka berdasarkan LVE

\begin{tabular}{cl}
\hline Tahap & Sikap anggota masyarakat terhadap bahasa mereka \\
\hline 5 & $\begin{array}{l}\text { Kesemua penutur menghargai bahasa mereka dan berharap bahasa mereka dapat } \\
\text { dipromosikan. }\end{array}$ \\
4 & $\begin{array}{l}\text { Kebanyakan penutur menyokong pelestarian bahasa. } \\
\text { Ramai penutur menyokong pelestarian bahasa; penutur lain tidak mengendahkan } \\
\text { atau mungkin menyokong kepupusan bahasa. }\end{array}$ \\
& $\begin{array}{l}\text { Sesetengah penutur menyokong pelestarian bahasa; penutur lain tidak } \\
\text { mengendahkan atau mungkin menyokong kepupusan bahasa. }\end{array}$ \\
& $\begin{array}{l}\text { Hanya beberapa ahli menyokong pelestarian bahasa; penutur lain tidak } \\
\text { mengendahkan atau mungkin menyokong kehilangan bahasa. }\end{array}$ \\
& $\begin{array}{l}\text { Tiada siapa mengendahkan kepupusan bahasa tersebut; kesemua penutur lebih } \\
\text { gemar menggunakan bahasa dominan. }\end{array}$ \\
\hline
\end{tabular}

Sumber: UNESCO (2003)

Bahasa Melayu Brunei dan bahasa Melayu standard diklasifikasikan dalam Tahap 5 kerana majoriti responden mempunyai sikap yang positif terhadap kedua-dua variasi bahasa ini. Penutur-penutur Melayu ini menggunakan bahasa Melayu Brunei sebagai penanda perpaduan dan pengenalpastian etnisiti dan kebangsaan, sekali gus mengukuhkan aspirasi mereka untuk menyampaikan bahasa Melayu Brunei sebagai bahasa pertama bagi generasi akan datang. Dalam masa yang sama, penutur-penutur Melayu ini juga berpegang teguh kepada bahasa Melayu standard berikutan status dan prestij bahasa ini, di samping menyokong penggunaannya bagi tujuan rasmi. Oleh yang demikian, sikap bahasa terhadap kedua-dua variasi bahasa tersebut adalah positif. 
Justifikasi bahasa Melayu Brunei dan bahasa Melayu standard dalam Tahap 5 juga mematuhi kriteria yang menekankan "ketika sikap penutur terhadap bahasa mereka adalah sangat positif, bahasa itu juga dianggap sebagai simbol utama bagi identiti sesebuah kelompok, selain sebagai inti kebudayaan yang penting kepada masyarakat penutur dan identiti etnik mereka" (UNESCO 2003, 14, terjemahan penulis). Ketiadaan sikap negatif terhadap bahasa Melayu Brunei dan bahasa Melayu standard dalam domain solidariti dan domain rasmi atau profesional juga menunjukkan bahawa penggunaan kedua-dua variasi bahasa ini tidak dilihat sebagai gangguan kepada mobiliti ekonomi dan peluang berintegrasi dalam masyarakat di Brunei.

"Sikap dasar kerajaan dan institusi bahasa, termasuk status rasmi dan penggunaan bahasa" merupakan satu lagi faktor penting dalam LVE yang berkait langsung dengan kajian sikap bahasa. Dengan menekankan faktor sikap bahasa dan dasar bahasa kebangsaan sebagai sebahagian daripada interaksi dan kesan sosial terhadap bahasa Melayu Brunei dan bahasa Melayu standard, jelas bahawa pengiktirafan dan dokumentasi rasmi yang menyokong keutamaan bahasa Melayu standard tidak mempengaruhi sikap positif terhadap bahasa Melayu Brunei, walaupun kedua-dua variasi bahasa mempunyai taraf dan nilai kuasa yang berbeza.

Kedua-dua institusi formal dan kemasyarakatan masih mengamalkan dan melestarikan penggunaan bahasa Melayu Brunei dan bahasa Melayu standard berdasarkan keperluan dan persekitaran. Perkara ini juga mungkin disebabkan tiadanya kenyataan jelas yang pernah dikeluarkan oleh pihak kerajaan untuk menghalang penggunaan kepelbagaian bahasa di Brunei, walaupun tiada sebarang galakan untuk mengamalkannya (Noor Azam 2005). Walaupun bahasa Melayu standard diiktiraf dalam domain rasmi atau formal, keadaan ini tidak menghalang penutur-penutur Melayu untuk menggunakan bahasa Melayu Brunei dan bahasa Inggeris dalam domain yang sama. Malah, perkara ini tidak menimbulkan masalah terhadap kecekapan berbahasa dan kesedaran metalinguistik para penggunanya. Oleh yang demikian, sikap neutral dasar bahasa kebangsaan terhadap kepelbagaian bahasa tidak memberi kesan negatif kepada kecederungan penggunaan bahasa Melayu Brunei dan bahasa Melayu standard. Dalam aspek lain, dukungan falsafah negara (MIB) juga telah memperkuat impak positif kepada keberdayaan dan pelestarian kedua-dua variasi bahasa tersebut, seperti yang diakui oleh pakar-pakar bahasa menerusi temu bual yang dijalankan.

Dapatan kajian ini juga turut mencabar hipotesis yang menyatakan "ketika wujudnya pelbagai bahasa yang mempunyai nilai kuasa yang berbeza, penutur dari kelompok minoriti yang boleh menggunakan kedua-dua bahasa ibunda 
dan bahasa dominan akan beralih secara beransur-ansur untuk menggunakan bahasa dominan sahaja" (UNESCO 2003, 15, terjemahan penulis). Hal ini kerana dapatan kajian tidak menunjukkan sebarang petanda bahawa penuturpenutur Melayu akan atau telah meninggalkan bahasa pertama mereka (bahasa Melayu Brunei) untuk memudahkan mobiliti sosial, walaupun bahasa Melayu Brunei tidak diiktiraf secara rasmi seperti bahasa Melayu standard. Kajian turut mendapati penutur-penutur Melayu menerima fenomena kedwibahasaan yang melibatkan bahasa Melayu Brunei, bahasa Melayu standard dan bahasa Inggeris dengan positif. Kecenderungan positif terhadap kepelbagaian bahasa ini berlaku walaupun sejumlah besar kajian terdahulu mendakwa bahawa bahasa Inggeris (bahasa yang mempunyai status Tahap 1 [Antarabangsa] dalam EGIDS) menyebabkan kemerosotan bahasa Melayu di Brunei.

\section{Penggunaan Bahasa Melayu dan Bahasa Inggeris yang Saling Melengkapi}

Edwards (1993) telah mengenal pasti ciri-ciri kedwibahasaan yang stabil di Brunei kerana kurangnya tekanan dan desakan sosial serta pengaruh politik dalam perancangan bahasa kebangsaan dan dasar-dasar kedwibahasaan, berbanding negara-negara lain. Kajian ini memperluas pemerhatian Edwards (1993) dan menjelaskan bahawa terdapat kematangan dalam kestabilan kedwibahasaan melibatkan bahasa Melayu dan bahasa Inggeris di Brunei. Keadaan ini berikutan penerimaan positif yang sangat tinggi terhadap fenomena kedwibahasaan dalam kalangan responden kajian, sama ada secara dalaman atau luaran. Ketiadaan sikap negatif terhadap mana-mana bahasa juga menunjukkan bahawa sebahagian besar responden menerima baik bahasa Melayu dan bahasa Inggeris berdasarkan status, peranan dan penggunaan kedua-dua bahasa tersebut. Hal ini mungkin disebabkan oleh persekitaran linguistik yang lebih baik bagi perancangan dan penggubalan dasar bahasa di Brunei.

Tanda-tanda kestabilan kedwibahasaan juga dapat dikesan apabila dapatan kajian menunjukkan bahawa para penutur Melayu menganggap kedwibahasaan sebagai "cara hidup dan penggunaan kedua-dua bahasa dalam kehidupan seharian adalah norma dan bukannya pengecualian" ( $\mathrm{Ng}$ dan Wigglesworth 2007,20 , terjemahan penulis). Kematangan dalam kedwibahasaan juga dikesan memandangkan para penutur Melayu juga sangat selesa dan berkebolehan dalam menggunakan bahasa Melayu dan bahasa Inggeris mengikut keperluan dan persekitaran. Penutur-penutur Melayu ini turut mempunyai kesedaran tentang peranan bahasa-bahasa tersebut di peringkat individu, masyarakat dan negara.

Sebilangan pakar bahasa yang ditemu bual juga mengakui akan kestabilan kedwibahasaan bahasa Melayu dan bahasa Inggeris di Brunei. Kedua-dua 
pakar bahasa tempatan, Aminah Haji Momin dan Noor Azam Haji Othman dan pakar-pakar bahasa Melayu dari Indonesia, Malaysia dan Singapura turut mengesahkan kejayaan Brunei menerapkan MIB sebagai ideologi dan identiti kebangsaan serta penyebaran agama Islam yang membantu pelestarian bahasa Melayu dalam menghadapi arus globalisasi bahasa Inggeris. Perkara yang sama turut diakui oleh dua pakar bahasa antarabangsa, Paolo Coluzzi dan Andy Kirkpatrick yang menjelaskan bahawa hubungan baik antara bahasa Melayu dengan bahasa Inggeris di Brunei adalah disebabkan oleh sikap positif terhadap kedua-dua bahasa dan pelaksanaan dasar bahasa kebangsaan dan sistem pendidikan yang stabil. Tambahan lagi, situasi bahasa di Brunei juga tidak dipengaruhi oleh elemen-elemen persaingan politik, sekali gus membantu kepada kestabilan kedwibahasaan dan keberdayaan bahasa Melayu.

Komodifikasi bahasa Melayu dan bahasa Inggeris yang melibatkan pelbagai faktor seperti sokongan institusi, pasaran linguistik, demografi dan sosiobudaya turut menyumbang kepada situasi kedwibahasaan yang stabil dan mengurangkan kemungkinan berlakunya peralihan bahasa Melayu kepada bahasa Inggeris. Perkara ini juga mencabar andaian umum tentang pertembungan bahasa Melayu dan bahasa Inggeris di Brunei kerana kajian ini mendapati bahawa kedua-dua bahasa ini digunakan dalam konteks tertentu dan saling melengkapi antara satu sama lain. Walaupun dapatan analisis menunjukkan situasi kedwibahasaan di Brunei adalah stabil, namun masih terdapat keperluan untuk memantau ekologi bahasa yang melibatkan perubahan dasar, kecekapan bahasa dan sikap bahasa masyarakat Melayu dari masa ke masa, memandangkan elemen-elemen sosiolinguistik ini lazimnya bersifat dinamik.

Walaupun begitu, masih terdapat laporan dan kebimbangan terhadap kemerosotan keberdayaan bahasa-bahasa etnik minoriti yang lain disebabkan penggunaan bahasa Melayu dan bahasa Inggeris yang sangat meluas. Berbanding bahasa Melayu Brunei, bahasa Melayu standard dan bahasa Inggeris yang mempunyai status dan kepentingan yang jelas secara dalaman atau luaran, tiada status rasmi diberikan kepada bahasa-bahasa etnik minoriti yang lain. Malah, usaha melestarikan dan mencergaskan bahasa-bahasa tersebut masih kurang dijalankan. Keadaan ini mencetuskan kebimbangan dalam kalangan pakar bahasa etnik dan penutur-penutur setempat terhadap risiko kehilangan identiti dan elemen-elemen kebudayaan etnik tempatan (Coluzzi 2011; McLellan 2014; Najib 2020; Najib dan McLellan 2018). 


\section{Kesimpulan}

Melalui kajian berdasarkan rangka kerja yang berteraskan sikap bahasa sebagai indikator utama dan model-model keberdayaan bahasa, makalah ini membuktikan bahawa status dan nilai kepentingan bahasa Melayu standard tidak dapat dipertikaikan kerana pengiktirafan rasmi dan kebangsaan terus mempertahankan keberdayaan bahasa standard tersebut. Perkara yang sama turut dikesan pada bahasa Melayu Brunei yang dipraktikkan secara meluas dalam pelbagai situasi dan domain oleh masyarakat Melayu di Brunei. Bahasa Melayu Brunei memainkan peranan utama sebagai bahasa vernakular bagi penuturpenutur Melayu, selain menjadi kod pilihan utama dalam komunikasi antara etnik. Bahasa ini juga dianggap sebagai sebahagian daripada simbol identiti dan penanda perpaduan masyarakat Melayu Brunei. Selain itu, bahasa Melayu Brunei yang lazimnya dianggap sebagai variasi tidak formal turut memainkan peranan dalam memperkaya dan memberi nilai tambah kepada variasi standard tersebut. Hal ini kerana bahasa Melayu Brunei juga banyak menyumbang dari aspek perbendaharaan kata tempatan, sekali gus melestarikan penggunaan bahasa Melayu standard.

Kajian ini juga mendapati bahawa bahasa Inggeris hanya berperanan besar dalam kalangan masyarakat profesional dan untuk penggunaan akademik. Satu lagi dapatan penting ialah bahasa Melayu dan bahasa Inggeris mempunyai kewujudan yang harmonis di Brunei kerana para penutur Melayu mempunyai kesedaran metalinguistik yang tinggi dan bijak menyesuaikan penggunaan kedua-dua bahasa tersebut dalam kehidupan seharian. Dapatan dalam kajian ini turut memberi ruang kepada para penyelidik pada masa hadapan untuk menilai unsurunsur psikologi dan sosiologi dengan lebih teliti bagi memahami keberdayaan dan prospek sesebuah bahasa yang berada dalam ruang lingkup persekitaran kedwibahasaan atau keanekabahasaan.

\section{Nota}

1. Laman sesawang boleh diakses melalui https://www.ethnologue.com/.

\section{Bibliografi}

Abdullah Hassan. 2009. Bahasa Melayu di persimpangan: Antara jati diri dengan rempuhan globalisasi. KEMANUSIAAN the Asian Journal of Humanities 16: 59-81.

. 1983. Isu dan masalah standardisasi bahasa Malaysia. Dewan Bahasa May, 323-339. 
Ahmad, A.B. 1978. Bahasa Kedayan dalam satu penggolongan dengan bahasa Melayu Brunei. Dewan Bahasa 22(1), 8-18.

Aminah Awang Basar. 2015. Sikap generasi muda terhadap bahasa Melayu: Senario di Malaysia, Negara Brunei Darussalam dan Indonesia. Paper presented at the Seminar Penyelidikan Pendidikan Memartabatkan Bahasa Melayu (MBM), Institut Pendidikan Guru Kampus Tun Abdul Razak, Kota Samarahan, Sarawak, Malaysia, September.

Azhari Daman Darnis. 2016. Sikap bahasa generasi muda Indonesia, Malaysia dan, Brunei Darussalam menurut ciri sosial dan latar kebahasaan. Komisi penilitian MABBIM. Jakarta: Balai Bahasa.

Azmi Abdullah. 2009. SPN21 lays less stress on Malay, say experts. The Brunei Times, 24 April.

Baker, C. 1996. Foundations of bilingual education and bilingualism. 2nd Ed. Clevedon: Multilingual Matters. 1992. Attitudes and language. Clevedon: Multilingual Matters.

Bogner, A., Littig, B. and Menz, W. 2009. Introduction: Expert interviews; An introduction to a new methodological debate. In Interviewing experts, eds. A. Bogner, B. Littig and W. Menz, 1-16. Basingtoke, England: Palgrave Macmillan.

Clynes, A. 2001. Brunei Malay: An overview. Occasional Papers in Language Studies 7: $11-44$.

Clynes, A. and Deterding, D. 2011. Standard Malay (Brunei). Journal of the International Phonetic Association 41(2): 259-268. https://doi.org/10.1017/ S002510031100017X

Collins, J.T. 2002. "Malay is fourth largest language" and other myths: Language studies and ASEAN. Paper presented at the Persidangan Linguistik ASEAN ke-2: Bahasa Pengukuh Solidariti ASEAN, Universiti Brunei Darussalam, Brunei, 28-20 October.

Collins, J.T. and Zaharani Ahmad. 1999. The Malay language and ethnic identity in modern Malaysia. Akademika 55: 33-148.

Coluzzi, P. 2011. Majority and minority language planning in Brunei Darussalam. Language Problems and Language Planning 35(3): 222-240. https://doi.org/ 10.1075/lplp.35.3.02col

Darwis Harahap. 2000. Menuju bahasa yang satu, bahasa Melayu. Bahasa Jiwa Bangsa 2: $57-62$.

Doringer, S. 2020. Combining qualitative interviewing approaches for investigating implict expert knowledge. International Journal of Social Research Methodology 24(3): 265-278. https://doi.org/10.1080/13645579.2020.1766777

Dwyer, A.M. 2011. Tools and techniques for endangered-language assessment and revitalization. In Vitality and viability of minority languages. New York: Trace Foundation Lecture Series Proceedings. Retrieved from http://www.trace.org/ events/events_lecture_proceedings.html (accessed 25 August 2016).

Edwards, J. 1993. Implementing bilingualism: Brunei in perspective. In Bilingualism and national development, eds. G.M. Jones and C.K. Ożóg, 25-38. Clevedon: Multilingual Matters.

Fasold, R. 1984. The sociolinguistics of society. Oxford: Blackwell. 
Fathu Rahman. 2011. Bahasa Melayu menuju bahasa PBB: Suatu gagasan awal. In Prosiding kongres antarabangsa bahasa dan budaya, eds. Azurin Othman dan Norati Bakar, Vol. 2, 122-134. Bandar Seri Begawan: Dewan Bahasa dan Pustaka.

Fatimah Chuchu. 2010. Bahasa Melayu dalam Sistem Pendidikan Negara Abad ke-21 (SPN-21). Rampak Serantau 17: 276-286.

Fatimah Chuchu and Najib Noorashid. 2015. Code choice within intercultural communication among ethnic minority in Brunei. Indonesian Journal of Applied Linguistics 5(1): 86-94. http://dx.doi.org/10.17509\%2Fijal.v5i1.835

Fishman, J. 1991. Reversing language shift. California: Multilingual Matters.

Garrett, P. 2010. Attitudes to language. Cambridge: Cambridge University Press. https://doi.org/10.1017/CBO9780511844713

Giles, H., Noels, K., Ota, H., Ng. S.H., Gallois, C., Ryan, E.B., Williams, A., Lim, T.S., Somera, L., Tao, H. and Sachdev, I. 2000. Age vitality across eleven nations. Journal of Multilingual and Multicultural Development 21(4): 308-323. https://doi.org/10.1080/01434630008666407

Hashim Musa, Rozita Che Rodi, Halimah Pondo and Salmah Jan Noor Muhammad. 2013. Bahasa Melayu dan konsep kebenaran ilmu berdasarkan pandangan Syed Muhammad Naquib al-Attas. KEMANUSIAAN the Asian Journal of Humanities 20(1): 1-22.

Husni Abu Bakar. 2009. Code-switching in Kuala Lumpur Malay: The "rojak" phenomenon. EXPLORATIONS 9: 99-107.

Ishamina, A. and Deterding, D. 2017. English-medium education in a university in Brunei Darussalam: Codeswitching and intelligibility. In English medium instruction in higher education in Asia-Pacific: From policy to pedagogy, eds. B. FentonSmith, P. Humphreys and I. Walkinshaw, 281-298. Dordrecht, Netherlands: Springer. https://doi.org/10.1007/978-3-319-51976-0_15

Jones, G.M. 1996. The changing role of English in Brunei Darussalam. Paper presented at the English in Southeast Asia Conference, Singapore, 21-23 November.

Lewis, M.P. and Simons, G.F. 2010. Assessing endangerment: Expanding Fishman's GIDS. Romanian Review of Linguistics 55(2): 103-120. https://doi.org/10.1017/ CBO9780511783364.003

Lewis, M.P., Simons, G.F. and Fennig, C.D. 2015. Ethnologue: Languages of the world. 18th Ed. Texas: SIL International.

Martin, P.W. 1996. Brunei Malay and bahasa Melayu: A sociolinguistic perspective. In Language use and language change in Brunei Darussalam, eds. P.W. Martin, C. Ożóg and G. Poedjosoedarmo, 27-36. Ohio: Center of International Studies.

Martin, P.W. and Poedjosoedarmo, G. 1996. Introduction: An overview of the language situation in Brunei Darussalam. In Language use and language change in Brunei Darussalam, eds. P.W. Martin, C. Ożóg dan G. Poedjosoedarmo, 1-26. Ohio: Center of International Studies.

Mataim Bakar. 2001. Bahasa Melayu dalam sistem pendidikan dwibahasa Negara Brunei Darussalam. Bahasa Jiwa Bangsa 4: 213-230.

McLellan, J. 2014. Strategies for revitalizing endangered Borneo languages: A comparison between Negara Brunei Darussalam and Sarawak, Malaysia. Southeast Asia: A Multidisciplinary Journal 14: 14-22. 
2005. Malay-English language alternation in two Brunei Darussalam online discussion forums. PhD diss., Curtin University of Technology.

1997. Linguistic imperialism and the cultural politics of EIL. In The context of Southeast Asia: Outsiders' and insiders' perspectives on the roles of English, 156-165. Singapore: National Institute of Education.

McLellan, J. and Chua-Wong, P. 2002. Two languages in the classroom: Clashing codes or coexistence? ACELT Journal 6(2): 11-19.

Meuser, M. and Nagel, U. 2009. The expert interview and changes in knowledge production. In Interviewing experts, eds. A. Bogner, B. Littig and W. Menz, 17-42. Basingtoke, England: Palgrave Macmillan.

Najib Noorashid. 2020. A study on atttitudes towards the Malay language and its vitality in Brunei, Malaysia, Indonesia and Singapore. PhD diss., Universiti Brunei Darussalam.

Najib Noorashid and McLellan, J. 2021. "I speak English, but I'm still a Malay": Language attitudes and identity amongst bilingual Bruneians living in London. rEFLections 28(1): 121-143.

2018. Teaching and learning an ethnic minority language at university level: The case of Dusun in Brunei. GEMA Online Journal of Language Studies 18(1): 217-233.

Ng, B.C. and Wigglesworth, G. 2007. Bilingualism: An advanced resource book. Oxon, UK: Routledge.

Noor Azam Haji-Othman. 2005. Changes in the linguistic diversity of Negara Brunei Darussalam. PhD diss., University of Leicester.

Noor Azam Haji-Othman dan Siti Ajeerah Najib. 2016. The state of indigenous languages in Brunei. In The use and status of language in Brunei, eds. Noor Azam HajiOthman, J. McLellan dan D. Deterding, 17-29. Singapore: Springer.

Nothofer, B. 1991. The language of Brunei Darussalam. In Papers in Pacific linguistics, $A-81$, ed. H. Steinhauer. Canberra: Australian National University.

Nurhayati. 2009. Mengembangkan kebersamaan antarabangsa melalui bahasa. Paper presented at the Seminar Nasional Dies Natalis ke-44 FIB Undip: Mengembangkan Kebersamaan Masyarakat ASEAN Melalui Pendekatan Budaya, Semarang, Indonesia, 27 Oktober.

Ożóg, A.C.K. 1996. The unplanned use of English: The case of Brunei Darussalam. In Language use and language change in Brunei Darussalam, eds. P.W. Martin, C. Ożóg dan G. Poedjosoedarmo, 156-172. Ohio: Center of International Studies.

Rabiatul Kamit. 2012. Bahasa rojak affecting Malay language. The Brunei Times, 22 April. Retrieved from http://www.bt.com.bn/news-national/2012/04/22/bahasa-rojakaffecting-malay-language (accessed 11 May 2016).

Ronnlund, M., Nyberg, L., Backman, L. and Nilsson, L.G. 2005. Stability, growth, and decline in adult life span development of declarative memory: Crosssectional and longitudinal data from a population-based study. Psychology and Aging 20(1): 3-18. https://doi.org/10.1037/0882-7974.20.1.3

Saxena, M. 2006. Multilingual and multicultural identities in Brunei Darussalam. In Language policy, culture and identity in Asian contexts, eds. A. Tsui dan J. Tollefson, 262-303. Mahwah, NJ: Lawrence Erlbaum. 
Saxena, M. and Sercombe, P. 2002. Patterns and variations in language attitudes and language choices among Bruneians. In Education and society in plurilingual contexts, eds. W.C. Daniel dan G.M. Jones, 248-265. Brussels: VUB Press.

Syah, S. 2007. "Bahasa rojak" and the fate of the Malay language. The Brunei Times, 28 June. Retrieved from http://www.bt.com.bn/classification/opinion/2007/06/28/ bahasa_rojak_and the_fate_of_the_malay_language (accessed 29 April 2016).

Trudgill, P. 2003. A glossary of sociolinguistics. Oxford: Oxford University Press.

UNESCO (United Nations Educational, Scientific and Cultural Organization). 2011. UNESCO's Language vitality and endangerment methodological guideline: Review of application and feedback since 2003. Paper presented at the UNESCO's Culture Sector for Expert Meeting "Towards UNESCO guidelines on Language Policies: A Tool for Language Assessment and Planning”, Paris, 30 May-1 June.

2003. Language vitality and endangerment. Paper presented at the International Expert Meeting on UNESCO Programme Safeguarding of Endangered Languages, Paris, 10-12 March.

Wood, A., Swan, J., Elgar, A. and Alkaff, S.N.H. 2001. Shifting sands: Malay in place of English, English for Malay; Language in the workplace in Brunei Darussalam. Paper presented at the Conference of Plurilingual Hubs in the New Millennium, Hong Kong Polytechnic University, Hong Kong, 9-11 January.

Zaim Mahmud. 2010. Sikap bahasa dalam kalangan mahasiswa dan mahasiswi Universiti Brunei Darussalam dan Institut Teknologi Brunei. BA diss., Universiti Brunei Darussalam. 